\title{
MSEICR Fractional Order Mathematical Model of The Spread Hepatitis B
}

\section{Model Matematika Orde Fractional MSEICR pada Penyebaran Penyakit Hepatitis B}

\author{
Suriani..M ${ }^{1^{*}}$, Syamsuddin Toaha ${ }^{2^{* *}}$, Kasbawati $^{3^{*}}$
}

\begin{abstract}
.
This research aims to develop the MSEICR model by reviewing fractional orders on the spread of Hepatitis B by administering vaccinations and treatment, and analyzing fractional effects by numerical simulations of the MSEICR mathematical model using the method Grunwald Letnikov. Researchers use qualitative methods to achieve the object of research. The steps are to determine the MSEICR model by reviewing the fractional order, looking for endemic equilibrium points for each non-endemic and endemic equilibrium point, determining the equality of characteristics and eigenvalues of the Jacobian matrix. Next, look for values $R_{0}$ (Basic Reproductive Numbers), analyze stability around non-endemic and endemic equilibrium points and complete numerical simulations. From the simulation provided, it is known that by giving a fractional alpha value of $\alpha=0.5,0.75,0.8,0.9$ and 0.95 , the greater the value of the fractional order parameters used, the movement of the solution graphs is getting closer to the equilibrium point. If given $\alpha=$ $0.5,0.75$, and 0.8 still endemic, whereas if 0.9 and 0.95 the value is increased to non-endemic, then the number of hepatitis B sufferers will disappear.
\end{abstract}

Keywords : Hepatitis B, Fractional orde MSEICR model, Stability analysis.

\begin{abstract}
Abstrak
Peneletian ini bertujuan untuk mengembangkan model MSEICR dengan meninjau orde fraksional pada penyebaran penyakit Hepatitis B dengan pemberian vaksinasi dan pengobatan, dan menganalisis efek fraksional dengan simulasi numerik model matematika MSEICR menggunakan metode Grunwald Letnikov. Peneliti menggunakan metode kualitatif untuk mencapai objek penelitian. Langkah-langkahnya adalah menentukan model MSEICR dengan meninjau orde fraksional, mencari titik kesetimbangan endemik untuk setiap titik kesetimbangan non-endemik dan endemik, menentukan persamaan karakteristik dan nilai eigen matrik Jacobian. Selanjutnya, mencari nilai $R_{0}$ (Bilangan Reproduksi Dasar), menganalisis kestabilan disekitar titik kesetimbangan non-endemik dan endemik dan menyelesaian simulasi numerik. Dari simulasi yang diberikan diketahui bahwa dengan memberikan nilai alpha fraksional sebesar $\alpha=0.5,0.75,0.8,0.9$ dan 0.95 , semakin besar nilai parameter orde fraksional yang digunakan, maka pergerakan grafik solusi semakin mendekati titik kesetimbangan. Jika diberikan $\alpha=$ 0.5, 0.75 dan 0.8 masih terjadi endemik sedangkan jika nilai $\alpha$ ditingkatkan menjadi 0.9 dan 0.95 maka terjadi non-endemik, akibatnya jumlah penderita hepatitis B akan hilang.
\end{abstract}

* Program Studi Magister Matematika, FMIPA-UNHAS

Email: ${ }^{1}$ Surianiyani01f@gmail.com, ${ }^{2}$ syamsuddint@gmail.com, ${ }^{3}$ kasbawati@gmail.com 


\section{Suriani.M, Syamsuddin Toaha, Kasbawati \\ Jurnal Matematika, Statistika E Komputasi}

Kata kunci : Hepatitis B, Orde fraksional, Analisis kestabilan.

\section{Pendahuluan}

Hepatitis adalah penyakit peradangan hati. Kondisi ini dapat membatasi diri atau dapat berkembang menjadi fibrosis (jaringan parut), sirosis atau kanker hati. Ada lima virus hepatitis utama, yaitu tipe A, B, C, D dan E. Kelima jenis ini menjadi perhatian terbesar karena beban penyakit dan kematian yang ditimbulkannya dan potensi penyebaran wabah dan epidemi. Infeksi hepatitis B dan C menyebabkan penyakit hati kronis pada ratusan juta orang. Sehingga menjadi penyebab paling umum dari sirosis hati dan kanker hati [12]. Virus hepatitis telah menjadi tantangan kesehatan masyarakat secara global. Meskipun ada 5 jenis virus hepatitis yang berbeda, hepatitis B kronis dan C menyebabkan $95 \%$ mengidap penyakit hepatitis dan kematian dini. Hepatitis D kurang umum dan hanya terjadi dalam hubungan dengan Hepatitis B. Virus lain (yaitu hepatitis A \& E) menyebar melalui makanan dan air yang terkontaminasi dan menyebabkan infeksi akut serta wabah di daerah-daerah yang miskin sanitasi dan pembuangan limbah yang tidak memadai. Infeksi akut sering berumur pendek dan sembuh dalam beberapa minggu. Epidemi virus hepatitis B dan C menyebabkan 325 juta orang secara global dan 10 kali lebih besar dari epidemi HIV secara global. Setiap hari, lebih dari 3600 orang meninggal karena penyakit hati yang disebabkan virus hepatitis, gagal hati dan kanker hati [13]. Pemberian vaksinasi pada bayi yang baru lahir dapat berpengaruh dalam upaya pencegahan penyakit hepatitis B. Salah satu pencegahan penyakit hepatitis B yang paling efektif yaitu dengan melakukan suntik vaksinasi hepatitis B. Pemberian vaksin dilakukan sebanyak 3 kali, yaitu pada saat bayi baru lahir, anak usia 1 bulan dan 3-6 bulan. Maka dari itu, pemerintah mewajibkan pada orang tua untuk melakukan imunisasi hepatitis pada bayi dan anak-anak untuk mencegah dan melindungi dari penyakit hepatitis B.

Model matematika merupakan sekumpulan persamaan dan pertidaksamaan matematika yang menginterpretasikan permasalahan dunia nyata dalam bahasa matematika. Model matematika juga dipandang sebagai proses membangun suatu model untuk menggambarkan dinamika suatu sistem, sehingga dapat diketahui atau diperkirakan sesuatu yang akan terjadi pada sistem tersebut dalam jangka waktu tertentu [11]. Pemodelan matematika banyak digunakan dalam berbagai disiplin ilmu, salah satunya adalah ilmu kesehatan. Pemodelan matematika dibidang kesehatan dikenal sebagai model epidemiologi [10] Muin dkk [8] menganalisis suatu modifikasi model SEIR untuk mengetahui penyebaran penyakit hepatitis dengan mengambil vaksin dan pengobatan kepada kelompok yang masuk sebagai penyakit hepatitis, yang membagi kompartemen menjadi enam MSEICR yaitu immunized individual $(M)$, susceptible $(S)$, exposed $(E)$, infection indivisuals $(I)$, carriers $(C)$, recovered $(R)$ dan menganalis model tersebut dalam bentuk sistem persamaan differensial biasa (SPDB). Pendekatan turunan fraksional yang digunakan dalam penelitian ini adalah turunan fraksional Caputo. Angstman dkk [1] menganalisis dan memodifikasi model matematika SIR yang berbentuk SPDB nonlinear kedalam bentuk SPDF. Das dan Gupta [3] sistem persamaan differensial orde fraksional (SPDF) diperoleh dari sistem persamaan differensial nonlinear sehingga turunan pertama dari sistem persamaan differensial tersebut menjadi turunan fraksional orde $\boldsymbol{\alpha}$ dengan $\mathbf{0}<\boldsymbol{\alpha} \leq \mathbf{1}$ pada model Lotka-Volterra.

\section{Model Matematika Orde Fraksional MSEICR}

Model MSEICR merupakan pengembangan dari model SEIR yang secara umum terbagi menjadi empat kompartemen yaitu susceptible $(S)$, exposed $(E)$, infected $(I)$, dan recovered $(R)$ [7]. Pada tulisan ini, penyakit hepatitis B dikembangkan menjadi model MSEICR orde fraksional dengan membagi populasi manusia menjadi enam kompartemen yaitu: immunized individuals $(M)$, susceptible individuals $(\mathrm{S})$, exposed $(E)$, infection individuals $(I)$, carriers $(C)$, dan recovered $(R)$ seperti yang telah dilakukan oleh Muin dkk [8]. Model MSEICR diasumsikan bayi baru lahir yang diimunisasi masuk ke dalam kompartemen immunized individuals $(M)$ dengan laju $c A$. Bayi baru lahir yang tidak 


\section{Suriani.M, Syamsuddin Toaha, Kasbawati \\ Jurnal Matematika, Statistika \& Komputasi}

diimunisasi dengan laju $(1-c) A$ dan yang telah habis pengaruh imunisasinya dengan laju $\psi M$ masuk ke dalam kompartemen rentan. Individu yang masuk ke dalam kompartemen rentan, jika mendapatkan vaksin dengan laju $u_{1} S$ maka akan berpindah ke kompartemen pulih recovered $(R)$.

Individu yang rentan melakukan kontak dengan individu yang terinfeksi dan pembawa. Individu tersebut berpindah ke kompartemen exposed $(E)$ dengan laju $\rho(I+\theta C) S$. Individu yang telah terpapar penyakit dalam kompartemen exposed $(E)$ berpindah ke kompartemen infeksi dengan laju $\eta_{1} E$. Individu infeksi akut berpindah ke kompartemen carriers $(C)$ dengan laju $p \eta_{2} I$, dan individu infeksi akut dengan HBV jernih berpindah dari kompartemen infection individuals (I) ke kompartemen recovered $(R)$ dengan laju (1p) $\eta_{2} I$. Individu pembawa jika mendapatkan pengobatan maka akan berpindah ke kompartemen recovered $(R)$ dengan laju $u_{2} C$ dan pemulihan spontan individu dan bergerak dari kompartemen carriers $(C)$ ke kompartemen recovered $(R)$ dengan laju $\eta_{3} E$. Hilangnya kekebalan individu yang sebelumnya dari kompartemen recovered $(R)$ berpindah ke kompartemen susceptible $(S)$ dengan laju konstanta sebesar $\eta_{4} R$. Setiap kompartemen dari 6 kompartemen dalam populasi memiliki tingkat kematian sendiri. Berdasarkan asumsi tersebut diperoleh sistem persamaan orde fraksional sebagai berikut

$$
\begin{gathered}
\frac{d M^{\alpha}(t)}{d t^{\alpha}}=c A-\beta M-\psi M, \\
\frac{d S^{\alpha}(t)}{d t^{\alpha}}=(1-c) A+\psi M-\beta S-\rho(I+\theta C) S-u_{1} S+\eta_{4} R, \\
\frac{d E^{\alpha}(t)}{d t^{\alpha}}=\rho(I+\theta C) S-\eta_{1} E-\beta E, \\
\frac{d I^{\alpha}(t)}{d t^{\alpha}}=\eta_{1} E-p \eta_{2} I-\beta I-(1-p) \eta_{2} I, \\
(2.1) \\
\frac{d C^{\alpha}(t)}{d t^{\alpha}}=p \eta_{2} I-\beta C-u_{2} C-\eta_{3} C, \\
\frac{d R^{\alpha}(t)}{d t^{\alpha}}=u_{2} C+\eta_{3} C+(1-p) \eta_{2} I+u_{1} S-\eta_{4} R-\beta R .
\end{gathered}
$$

\begin{tabular}{|c|c|c|}
\hline Parameter/Variabel & Deskripsi & Nilai \\
\hline$c$ & Populasi kelahiran baru & 0.1 \\
\hline$\beta$ & Kematian alami & 0.0121 \\
\hline$\rho$ & Laju tranmisi & $0.8-20.49$ \\
\hline$\psi$ & Tingkat berakhirnya keberhasilan vaksin & 0.0015 \\
\hline$\theta$ & Infeksi pembawa relatif terhadap infeksi akut & $0-1$ \\
\hline$\eta_{1}$ & $\begin{array}{l}\text { Laju perpindahan individu terpapar ke } \\
\text { terinfeksi akut }\end{array}$ & 0.6 \\
\hline$\eta_{2}$ & $\begin{array}{l}\text { Laju dimana individu meninggalkan } \\
\text { kompartemen infeksi akut }\end{array}$ & 0.8 \\
\hline$\eta_{3}$ & $\begin{array}{l}\text { Laju perpindahan individu pembawa ke } \\
\text { kompartemen pemulihan }\end{array}$ & 0.025 per year \\
\hline$\eta_{4}$ & Laju hilangnya pemulihan & 0.6 per year \\
\hline$P$ & $\begin{array}{l}\text { Proporsi individu infeksi akut menjadi } \\
\text { pembawa }\end{array}$ & 0.1 \\
\hline$u_{1}$ & $\begin{array}{l}\text { Proporsi perpindahan individu dari } \\
\text { kompartemen rentan ke kompartemen } \\
\text { pemulihan dengan vaksinasi }\end{array}$ & 0.11 \\
\hline$u_{2}$ & $\begin{array}{l}\text { Proporsi pembawa yang pindah ke } \\
\text { kompartemen pemulihan dengan pengobatan }\end{array}$ & 0.1 \\
\hline$M$ & Jumlah individu yang diimunisasi & 0.2 \\
\hline$S$ & Jumlah individu yang rentan & 0.94 \\
\hline
\end{tabular}

Keterangan variabel dan parameter model diberikan pada Tabel 2.1.

Tabel 2.1. Keterangan variabel dan parameter model MSEICR 
Suriani.M, Syamsuddin Toaha, Kasbawati

Jurnal Matematika, Statistika \& Komputasi

\begin{tabular}{lll}
\hline$E$ & Jumlah individu yang terpapar hepatitis B & 0.8 \\
$I$ & Jumlah individu yang terinfeksi hepatitis B & 0.5 \\
$C$ & Jumlah individu yang pembawa hepatitis B & 0.9 \\
$R$ & Jumlah individu yang sembuh dari penyakit & 0 \\
\hline
\end{tabular}

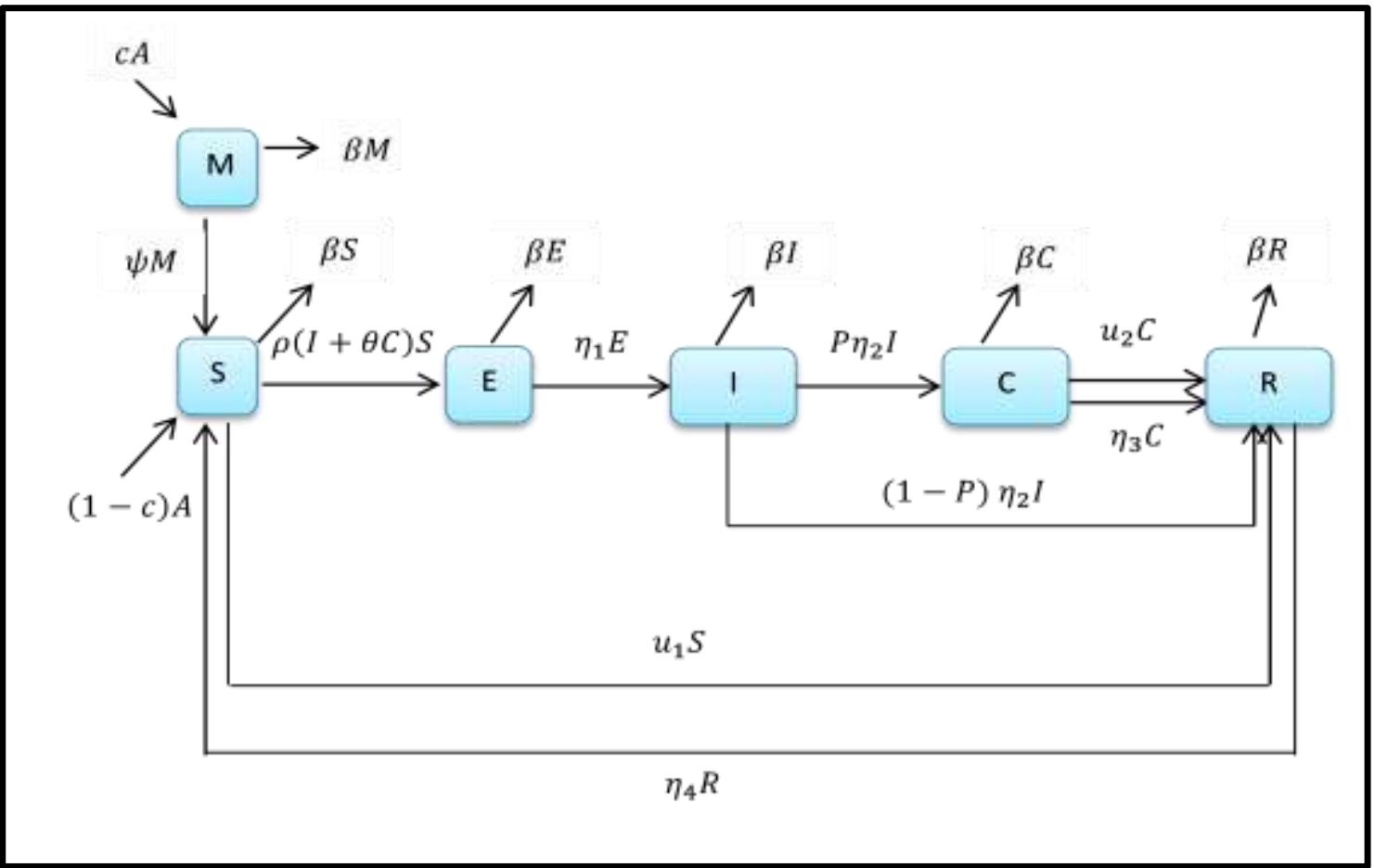

Gambar 2.1. Skema penyebaran penyakit hepatitis B MSEICR dengan pemberian vaksin dan pengobatan.

Persamaan differensial (PD) adalah persamaan yang memuat hubungan antara suatu fungsi yang tidak diketahui dengan satu atau lebih turunannya. Berdasarkan banyaknya variabel bebas, persamaan differensial dibagi menjadi dua yaitu, persamaan differensial biasa (PDB) dan persamaan differensial parsial (PDP). Persamaan differensial biasa adalah persamaan differensial yang hanya memuat satu variable bebas. Persamaan differensial parsial adalah persamaan differensial yang memuat lebih dari satu variable bebas [2].

Pada tahun 1918, lacroix menjadi matematikawan pertama yang mendefinisikan turunan fraksional. Misalkan $v=t^{m}$, dengan $m$ adalah bilangan bulat positif dan $n$ adalah bilangan rasional. Lacroix mendefinisikan turunan ke- $n$ dari suatu fungsi $v$ sebagai berikut :

$$
\frac{d^{n} t}{d t^{n}}=\frac{d^{n} t^{m}}{d t^{n}}=\frac{m !}{(m-n) !} t^{m-n}, \quad m \geq n
$$

\section{Hasil dan Pembahasan}

Berdasarkan sistem (2.1), jumlah populasi konstan/tetap sehingga $N(t)=V(t)+$ $S(t)+E(t)+I(t)+R(t)$. Persamaan (2.1) dapat disederhanakan dengan membentuk menjadi bentuk proporsi antara banyaknya individu dalam suatu subpopulasi dengan banyaknya populasi total. Misalkan $x_{1}=\frac{M(t)}{N(t)}, x_{2}=\frac{S(t)}{N(t)}, x_{3}=\frac{E(t)}{N(t)}, x_{4}=\frac{I(t)}{N(t)}, x_{5}=$ $\frac{C(t)}{N(t)}, x_{6}=\frac{R(t)}{N(t)}$, yang jika disubtitusikanke sistem (2.1) maka diperoleh 
Suriani.M, Syamsuddin Toaha, Kasbawati

Jurnal Matematika, Statistika \& Komputasi

$$
\begin{gathered}
\frac{d x_{1}}{d t}=c \beta-\beta x_{1}-\psi x_{1}, \\
\frac{d x_{2}}{d t}=(1-c) \beta+\psi x_{1}-\beta x_{2}-\rho\left(x_{4}+\theta x_{5}\right) x_{2}-u_{1} x_{2}+\eta_{4} x_{6}, \\
\frac{d x_{3}}{d t}=\rho\left(x_{4}+\theta x_{5}\right) x_{2}-\eta_{1} x_{3}-\beta x_{3}, \\
\frac{d x_{4}}{d t}=\eta_{1} x_{3}-\beta x_{4}-\eta_{2} x_{4}, \\
\frac{d x_{5}}{d t}=p \eta_{2} x_{4}-\left(\beta+u_{2}+\eta_{3}\right) x_{5}, \\
\frac{d x_{6}}{d t}=\left(u_{2}+\eta_{3}\right) x_{5}+(1-p) \eta_{2} x_{4}+u_{1} x_{2}-\left(\eta_{4}+\beta\right) x_{6} .
\end{gathered}
$$

Karena model (3.2) adalah sistem non-linear, maka hanya akan diselidiki dan dianalisis perilaku titik-titik kesetimbangan lokal pada model. Dari sistem (3.2) diperoleh matriks Jacobian

$$
=\left(\begin{array}{cccccc}
-(\beta+\psi) & 0 & 0 & 0 & 0 & 0 \\
\psi & -\left(\beta+u_{1}+\rho\left(x_{4}+\theta x_{5}\right)\right) & 0 & -\rho x_{2} & -\rho \theta x_{2} & \eta_{4} \\
0 & \rho\left(x_{4}+\theta x_{5}\right) & -\left(\eta_{1}+\beta\right) & \rho x_{2} & \rho \theta x_{2} & 0 \\
0 & 0 & \eta_{1} & -\left(\beta+\eta_{2}\right) & 0 & 0 \\
0 & 0 & 0 & P \eta_{2} & -\left(\beta+u_{2}+\eta_{3}\right) & 0 \\
0 & u_{1} & 0 & (1-P) \eta_{2} & u_{2}+\eta_{3} & -\left(\eta_{4}+\beta\right)
\end{array}\right)
$$

Titik-titik kesetimbangan non-endemik dan endemik dari sistem (3.2) tercapai ketika semua laju kompartemen ditetapkan menjadi $0, \frac{d x_{1}}{d t}=0, \frac{d x_{2}}{d t}=0, \frac{d x_{3}}{d t}=0, \frac{d x_{4}}{d t}=0, \frac{d x_{5}}{d t}=$ $0, \frac{d x_{6}}{d t}=0$. Dengan demikian diperoleh

$$
\begin{gathered}
c \beta-\beta x_{1}-\psi x_{1}=0 \\
(1-c) \beta+\psi x_{1}-\beta x_{2}-\rho\left(x_{4}+\theta x_{5}\right) x_{2}-u_{1} x_{2}+\eta_{4} x_{6}=0 \\
\rho\left(x_{4}+\theta x_{5}\right) x_{2}-\left(\eta_{1}+\beta\right) x_{3}=0 \\
\eta_{1} x_{3}-\left(\beta+\eta_{2}\right) x_{4}=0 \\
p \eta_{2} x_{4}-\left(\beta+u_{2}+\eta_{3}\right) x_{5}=0 \\
\left(u_{2}+\eta_{3}\right) x_{5}+(1-P) \eta_{2} x_{4}+u_{1} x_{2}-\left(\eta_{4}+\beta\right) x_{6}=0 .
\end{gathered}
$$

Titik kesetimbangan non-endemik pada sistem (3.2) tampil pada saat tidak ada penyebaran penyakit hepatitis B pada populasi. Kondisi ini terpenuhi ketika $x_{3}=0$ yang kemudian diikuti oleh $x_{4}=x_{5}=0$. Subtitusi $x_{3}=x_{4}=x_{5}=x_{6}=0$ pada persamaan (3.4), diperoleh titik kesetimbangan non-endemik

$$
\Sigma_{0}=\left(\frac{c \beta}{\beta+\psi}, \frac{\eta_{4} \psi-c \beta \eta_{4}+\eta_{4} \beta+\psi \beta-c \beta^{2}+\beta^{2}}{\beta^{2}+\eta_{4} \psi+\psi u_{1}+\eta_{4} \beta+\psi \beta+\beta u_{1}}, 0,0,0, \frac{u_{1}(\beta-c \beta+\psi)}{\left(\eta_{4} \beta+\psi \eta_{4}+\beta^{2}+\beta u_{1}+\beta \psi+\psi u_{1}\right)}\right)
$$

Titik kesetimbangan endemik merupakan keadaan saat penyakit menular menyebar dalam suatu populasi dan terjadi pada saat $x_{3}>0$ sehingga diperoleh

$$
\Sigma_{1}=\left(\frac{c \beta}{\beta+\psi}, \frac{(1-c) \beta+\psi\left(\frac{c \beta}{\beta+\psi}\right)+\eta_{4} x_{6}}{\rho\left(x_{4}+\theta x_{5}\right)+\left(\beta+u_{1}\right)}, \frac{\rho\left(x_{4}+\theta x_{5}\right) x_{2}}{c_{1}}, \frac{\eta_{1} x_{3}}{c_{2}}, \frac{p \eta_{2} x_{4}}{c_{3}}, \frac{\left(u_{2}+\eta_{3}\right) x_{5}+(1-p) \eta_{2} x_{4}+u_{1} x_{2}}{\left(\eta_{4}+\beta\right)}\right)
$$

dimana $\Sigma_{1} \in R_{+}^{6}$, keberadaan $\Sigma_{1} \in R_{+}^{6}$ akan dibuktikan melalui bilangan reproduksi dasar yang dijelaskan pada bagian selanjutnya. Jika sistem (3.2) dilinearkan di sekitar $\left(\Sigma_{0}\right)$ dan $\left(\Sigma_{1}\right)$, maka diperoleh matriks Jacobi 
Suriani.M, Syamsuddin Toaha, Kasbawati

Jurnal Matematika, Statistika \& Komputasi

$$
\begin{aligned}
J \Sigma_{0} & =\left[\begin{array}{cccccc}
-a & 0 & 0 & 0 & 0 & 0 \\
\psi & -b & 0 & -\rho x_{2_{0}} & -\rho \theta x_{2_{0}} & \eta_{4} \\
0 & 0 & -c & \rho x_{2_{0}} & \rho \theta x_{2_{0}} & 0 \\
0 & 0 & \eta_{1} & -d & 0 & 0 \\
0 & 0 & 0 & P \eta_{2} & -e & 0 \\
0 & u_{1} & 0 & (1-P) \eta_{2} & u_{2}+\eta_{3} & -f
\end{array}\right] \\
J \Sigma_{1} & =\left[\begin{array}{cccccc}
-g & 0 & 0 & 0 & 0 & 0 \\
\psi & -h & 0 & -\rho x_{2_{0}} & -\rho \theta x_{2_{0}} & \eta_{4} \\
0 & 0 & -j & \rho x_{2_{0}} & \rho \theta x_{2_{0}} & 0 \\
0 & 0 & \eta_{1} & -l & 0 & 0 \\
0 & 0 & 0 & P \eta_{2} & -l & 0 \\
0 & u_{1} & 0 & (1-P) \eta_{2} & u_{2}+\eta_{3} & -m
\end{array}\right]
\end{aligned}
$$

di mana $a=(\beta+\psi), b=\left(\beta+u_{1}\right), c=\left(\eta_{1}+\beta\right), d=\left(\beta+\eta_{2}\right), e=\left(\beta+u_{2}+\eta_{3}\right), f=\left(\eta_{4}+\beta\right)$, $g=(\beta+\psi), k=\left(\beta+\eta_{2}\right), h=\left(\beta+u_{1}+\rho\left(x_{4_{1}}+\theta x_{5_{1}}\right), l=\left(\beta+u_{2}+\eta_{3}\right), j=\left(\eta_{1}+\right.\right.$ $\beta), m=\left(\eta_{4}+\beta\right)$. Kestabilan $\Sigma_{1}$ dapat ditentukan melalui nilai eigen dari matriks Jacobi $J \Sigma_{1}$. Nilai eigen tersebut merupakan solusi dari persamaan karakteristik $\operatorname{det}\left(J \Sigma_{1}-\lambda I\right)=0$ [9], yaitu

$$
\begin{aligned}
& \left|\begin{array}{cccccc}
-a-\lambda & 0 & 0 & 0 & 0 & 0 \\
\psi & -b-\lambda & 0 & -\rho x_{2_{0}} & -\rho \theta x_{2_{0}} & \eta_{4} \\
0 & 0 & -c-\lambda & \rho x_{2_{0}} & \rho \theta x_{2_{0}} & 0 \\
0 & 0 & \eta_{1} & -d-\lambda & 0 & 0 \\
0 & 0 & 0 & P \eta_{2} & -e-\lambda & 0 \\
0 & u_{1} & 0 & (1-P) \eta_{2} & u_{2}+\eta_{3} & -f-\lambda
\end{array}\right|=0 \\
& (-a-\lambda)\left|\begin{array}{ccccc}
-b-\lambda & 0 & -\rho x_{2} & -\rho \theta x_{2_{0}} & \eta_{4} \\
0 & -c-\lambda & \rho x_{2_{0}} & \rho \theta x_{2_{0}} & 0 \\
0 & \eta_{1} & -d-\lambda & 0 & 0 \\
0 & 0 & P \eta_{2} & -e-\lambda & 0 \\
0 & 0 & (1-P) \eta_{2} & u_{2}+\eta_{3} & -f-\lambda
\end{array}\right|=0 \\
& (-a-\lambda)(-b-\lambda)\left|\begin{array}{cccc}
-c-\lambda & \rho x_{2_{0}} & \rho \theta x_{2_{0}} & 0 \\
\eta_{1} & -d-\lambda & 0 & 0 \\
0 & P \eta_{2} & -e-\lambda & 0 \\
0 & (1-P) \eta_{2} & u_{2}+\eta_{3} & -f-\lambda
\end{array}\right|=0 \\
& (-a-\lambda)(-b-\lambda)(-f-\lambda)\left|\begin{array}{ccc}
-c-\lambda & \rho x_{2_{0}} & \rho \theta x_{2_{0}} \\
\eta_{1} & -d-\lambda & 0 \\
0 & P \eta_{2} & -e-\lambda
\end{array}\right|=0
\end{aligned}
$$

sehingga diperoleh

$$
\begin{aligned}
& \lambda_{1}=-(\beta+\psi), \\
& \lambda_{2}=-\left(\beta+u_{1}\right), \\
& \lambda_{3}=-\left(\eta_{4}+\beta\right) .
\end{aligned}
$$

Karena $\lambda_{123}<0$ dan memenuhi $|\arg (z)|>\frac{\alpha \pi}{2}$ maka untuk menentukan kestabilan titik kesetimbangan $\Sigma_{0}$ adalah dengan menyelesaikan 
Suriani.M, Syamsuddin Toaha, Kasbawati

Jurnal Matematika, Statistika \& Komputasi

di mana

$$
\lambda^{3}+a_{1} \lambda^{2}+a_{2} \lambda+a_{3}=0,
$$

$$
\begin{gathered}
a_{1}=-c d e, \\
a_{2}=\rho \theta x_{2} \eta_{1}, \\
a_{3}=e \eta_{1} \rho x_{2} .
\end{gathered}
$$

Berdasarkan kriteria Routh Hurwitz, titik kesetimbangan $\Sigma_{0}$ yang merupakan polinomial ada 3 orde yaitu

maka dapat didefinisikan

$$
P(\lambda)=\lambda^{3}+a_{1} \lambda^{2}+a_{2} \lambda+a_{3}
$$

$$
\begin{aligned}
D(P) & =-\left|\begin{array}{ccccc}
1 & 0 & a_{2} & a_{3} & 0 \\
0 & 1 & a_{1} & a_{2} & a_{3} \\
3 & 2 a_{1} & a_{2} & 0 & 0 \\
0 & 3 & 2 a_{1} & a_{2} & 0 \\
0 & 0 & 3 & 2 a_{1} & a_{2}
\end{array}\right|, \\
& =18 a_{1} a_{2} a_{3}+\left(a_{1} a_{2}\right)^{2}-4 a_{3} a_{1^{3}}-4 a_{2^{3}}-27 a_{3^{2}} .
\end{aligned}
$$

Maka kestabilan $E_{0}$ ditentukan dengan proposisi

1. Jika $D(P)>0, a_{1}>0, a_{3}>0$, untuk semua $0<\alpha \leq 1$ atau

2. Jika $D(P)<0, a_{1} \geq 0, a_{2} \geq 0, a_{3}>0$, dan $\alpha<\frac{2}{3}$

3. Jika $D(P)<0, a_{1}>0, a_{1}>0, a_{1} a_{2}=a_{3}$ untuk semua $0<\alpha<1$ [6].

Suatu model biasanya memiliki parameter threshold yang dikenal sebagai bilangan reproduksi dasar $\left(\mathcal{R}_{0}\right)$, sedemikian sehingga jika $\mathcal{R}_{0}<1$ maka titik kesetimbangan nonendemik stabil asimtotik lokal dan penyakit tidak menyerang populasi, namun jika $\mathcal{R}_{0}>1$ maka titik kesetimbangan non-endemik tidak stabil dan penyakit sangat mungkin untuk menyebar [5]. $\mathcal{R}_{0}$ diperoleh dengan memisalkan $\mathcal{F}_{i}(x)$ sebagai laju penambahan infeksi baru pada kompartemen $i$ dan $\mathcal{V}_{i}(x)$ adalah laju perpindahan individu pada kompartemen $i$, maka $\mathcal{F}_{i}(x)$ dan $\mathcal{V}_{i}(x)$ dari sistem (3.2) adalah sebagai berikut

$$
\begin{gathered}
\mathcal{F}(x)=\left(\begin{array}{c}
\rho\left(x_{4}+\theta x_{5}\right) x_{2} \\
0 \\
0
\end{array}\right), \\
\mathcal{V}(x)=\left(\begin{array}{c}
\left(\eta_{1}+\beta\right) x_{3} \\
-\eta_{1} x_{3}+\left(\beta+\eta_{2}\right) x_{4} \\
-p \eta_{2} x_{4}+\left(\beta+u_{2}+\eta_{3}\right) x_{5}
\end{array}\right) .
\end{gathered}
$$

dari persamaan (3.7) dan (3.8) diperoleh matriks $F$ dan $V$ sebagai berikut

$$
\begin{aligned}
& F=\frac{\partial \mathcal{F}_{i}\left(\Sigma_{0}\right)}{\partial x_{j}}=\left(\begin{array}{ccc}
0 & \rho x_{2} & \rho \theta x_{2} \\
0 & 0 & 0 \\
0 & 0 & 0
\end{array}\right), \\
& (3.8) \\
& V=\frac{\partial \mathcal{V}_{i}\left(\Sigma_{0}\right)}{\partial x_{j}}=\left(\begin{array}{ccc}
c_{1} & 0 & 0 \\
-\eta_{1} & c_{2} & 0 \\
0 & -p \eta_{2} & c_{3}
\end{array}\right),
\end{aligned}
$$

dengan $c_{1}=\eta_{1}+\beta, c_{2}=\beta+\eta_{2}, c_{3}=\beta+u_{2}+\eta_{3}$. Invers dari matriks $V$ adalah: 
Suriani.M, Syamsuddin Toaha, Kasbawati

Jurnal Matematika, Statistika \& Komputasi

$V^{-1}(x)=\left(\begin{array}{ccc}\frac{1}{c_{1}} & 0 & 0 \\ \frac{\eta_{1}}{c_{1} c_{2}} & \frac{1}{c_{2}} & 0 \\ \frac{\eta_{1} p \eta_{2}}{c_{1} c_{2} c_{3}} & \frac{P \eta_{2}}{c_{2} c_{3}} & \frac{1}{c_{3}}\end{array}\right)$.

Nilai bilangan reproduksi dasar dari sistem (3.2) dapat ditentukan melalui matriks $F$ dan $V^{-1}$ tersebut. Dari persamaan (3.9) dan (3.11) diperoleh

$$
\begin{aligned}
F V^{-1} & =\left(\begin{array}{ccc}
0 & \rho x_{2} & \rho \theta x_{2} \\
0 & 0 & 0 \\
0 & 0 & 0
\end{array}\right)\left(\begin{array}{ccc}
\frac{1}{c_{1}} & 0 & 0 \\
\frac{\eta_{1}}{c_{1} c_{2}} & \frac{1}{c_{2}} & 0 \\
\frac{\eta_{1} p \eta_{2}}{c_{1} c_{2} c_{3}} & \frac{P \eta_{2}}{c_{2} c_{3}} & \frac{1}{c_{3}}
\end{array}\right), \\
& =\left(\begin{array}{ccc}
\frac{\rho x_{2} \eta_{1}}{c_{1} c_{2}}+\frac{\rho \theta x_{2}\left(\eta_{1} p \eta_{2}\right)}{c_{1} c_{2} c_{3}} & \frac{\rho x_{2}}{c_{2}}+\frac{\rho \theta x_{2}\left(p \eta_{2}\right)}{c_{2} c_{3}} & \frac{\rho \theta x_{2}}{c_{3}} \\
0 & 0 & 0 \\
0 & 0 & 0
\end{array}\right) .
\end{aligned}
$$

Selanjutnya nilai eigen dari matriks $F V^{-1}$ diperoleh degan menyelesaikan persamaan berikut:

$$
\left.\begin{array}{ccc}
\operatorname{det}\left(F(x) V^{-1}(x)-\lambda I\right) & = \\
\left(\left(\frac{\rho x_{2} \eta_{1}}{c_{1} c_{2}}+\frac{\rho \theta x_{2}\left(\eta_{1} p \eta_{2}\right)}{c_{1} c_{2} c_{3}}\right)-\lambda\right. & \frac{\rho x_{2}}{c_{2}}+\frac{\rho \theta x_{2}\left(p \eta_{2}\right)}{c_{2} c_{3}} & \frac{\rho \theta x_{2}}{c_{3}} \\
0 & -\lambda & 0 \\
0 & 0 & -\lambda
\end{array}\right)=0,
$$

dengan menyelesaikan persamaan $\operatorname{det}\left(F(x) V^{-1}(x)-\lambda I\right)=0$, maka diperoleh persamaan karakteristik

$$
\left(\left(\frac{\rho x_{2} \eta_{1}}{c_{1} c_{2}}+\frac{\rho \theta x_{2}\left(\eta_{1} p \eta_{2}\right)}{c_{1} c_{2} c_{3}}-\lambda\right)\right) \lambda^{2}=0 .
$$

Akar-akar dari persamaan karakteristik tersebut adalah $\lambda_{(1)}=\frac{\rho x_{2} \eta_{1}}{c_{1} c_{2}}+\frac{\rho \theta x_{2}\left(\eta_{1} p \eta_{2}\right)}{c_{1} c_{2} c_{3}}$ dan nilai eigen $\lambda_{(2,3)}=0$. Berdasarkan akar-akar persamaan karakteristik tersebut, spektral radius dari matriks next generation $F V^{-1}$ adalah $\lambda_{\max }=\frac{\rho x_{2} \eta_{1}}{c_{1} c_{2}}+\frac{\rho \theta x_{2}\left(\eta_{1} p \eta_{2}\right)}{c_{1} c_{2} c_{3}}$.Selanjutnya $\lambda_{\max }$ tersebut disebut sebagai $\mathcal{R}_{0}$.

$$
\mathcal{R}_{0}=\frac{\rho x_{2} \eta_{1}}{c_{1} c_{2}}+\frac{\rho \theta x_{2}\left(\eta_{1} p \eta_{2}\right)}{c_{1} c_{2} c_{3}}
$$

Jika nilai $c_{1}, c_{2}, c_{3}$ dan persamaan (3.12) disubstitusi ke persamaan (3.12) diperoleh $\mathcal{R}_{0}=\frac{\rho \eta_{1}\left(\eta_{4} \psi-c \beta \eta_{4}+\eta_{4} \beta+\psi \beta-c \beta^{2}+\beta^{2}\right)}{\left(\eta_{1}+\beta\right)\left(\beta+\eta_{2}\right)\left(\beta^{2}+\eta_{4} \psi+\psi u_{1}+\eta_{4} \beta+\psi \beta+\beta u_{1}\right)}+\frac{\rho \theta\left(\eta_{1} p \eta_{2}\right)\left(\eta_{4} \psi-c \beta \eta_{4}+\eta_{4} \beta+\psi \beta-c \beta^{2}+\beta^{2}\right)}{\left(\eta_{1}+\beta\right)\left(\beta+\eta_{2}\right)\left(\beta+u_{2}+\eta_{3}\right)\left(\beta^{2}+\eta_{4} \psi+\psi u_{1}+\eta_{4} \beta+\psi \beta+\beta u_{1}\right)}$ Hasil yang diperoleh dari bentuk $\frac{\partial \mathcal{R}_{0}}{\partial b \mu}<0$ dan $\frac{\partial \mathcal{R}_{0}}{\partial u}<0$ menunjukkan bahwa semakin besar proporsi efek vaksinasi dan pengobatan pada populasi hewan maka $\mathcal{R}_{0}$ akan semakin kecil sehingga titik kesetimbangan non-endemik stabil dan wilayah bebas dari penyakit.

\section{Simulasi Numerik}

Hasil solusi numerik solusi sistem 3.1 untuk mengilustrasikan hasil analisis pada subbab sebelumya. Simulasi numerik dilakukan dengan menggunakan metode Grunwald Letnikov nilai parameter yang digunakan dalam dengan mengasumsikan dan berdasarkan parameter-parameter yang digunakan dilihat pada tabel berikut 
Suriani.M, Syamsuddin Toaha, Kasbawati

Jurnal Matematika, Statistika $\mathcal{E}$ Komputasi

Tabel 3.1 Nilai Parameter

\begin{tabular}{cccc}
\hline Parameter & Nilai Parameter & Parameter & Nilai Parameter \\
\hline$c$ & 0.1 & $\eta 1$ & 0.6 \\
$\beta$ & 0.0121 & $\eta 2$ & 0.8 \\
$\rho$ & 0.5 & $\eta 3$ & 0.025 \\
$\psi$ & 0.0015 & $\eta 4$ & 0.6 \\
$\theta$ & 0.5 & $P$ & 0.1 \\
$u 1$ & 0.1 & $u 2$ & 0.11 \\
\hline
\end{tabular}

Nilai awal yang digunakan dalam simulasi ini $M(0)=0.2, S(0)=0.94, E(0)=0.8$, $I(0)=0.5, C(0)=0.9, R(0)=0$. Berdasarkan nilai parameter pada tabel 3.1 serta nilai $a 1=0.0681, a 2=0.0017$ dan $a 3=0.0502$ maka diperoleh titik kesetimbangan bebas penyakit $\quad \Sigma_{0}=(0.088,0.772,0,0,0,0.138), \lambda_{1}=-0.7021, \lambda_{2}=-0.0121, \lambda_{3}=$ $\left.-1.2020, \lambda_{4}=-0.2589, \lambda_{5}=-0.0002, \lambda_{6}-0.136\right)$ dan $R_{0}=0.9961$.

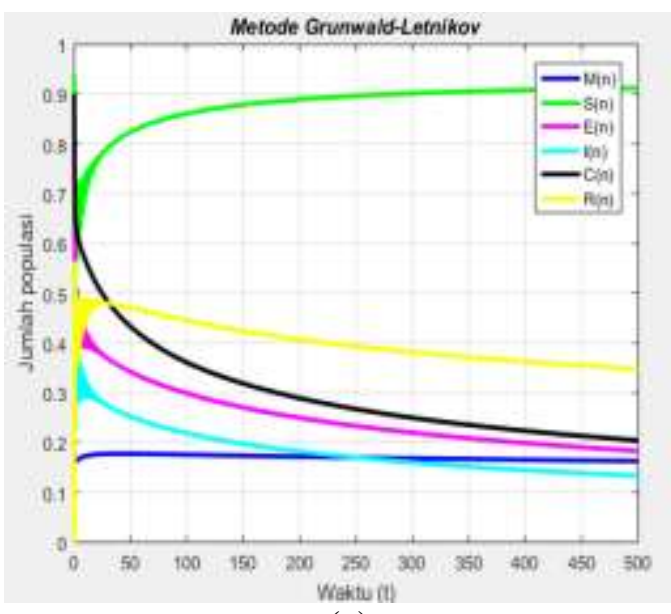

(a)

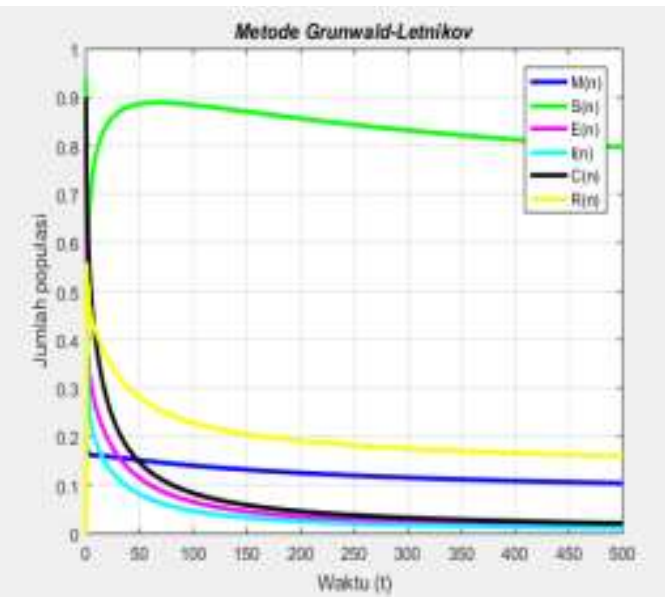

(b)

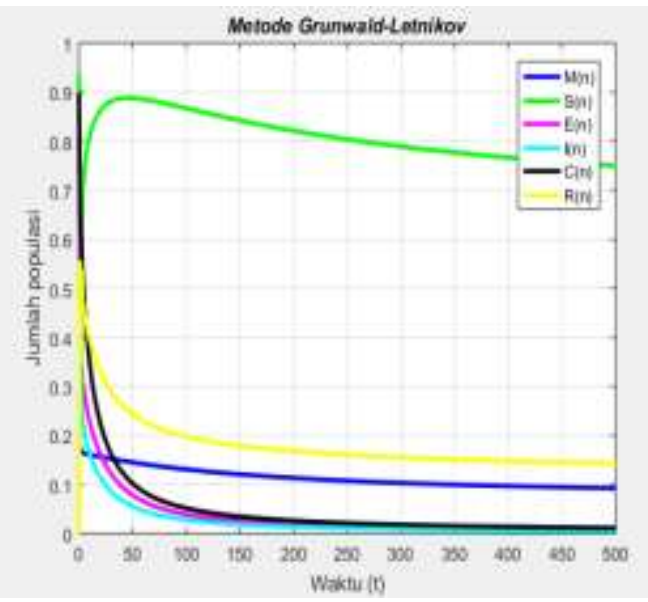

(c) 


\section{Suriani.M, Syamsuddin Toaha, Kasbawati Jurnal Matematika, Statistika \& Komputasi}

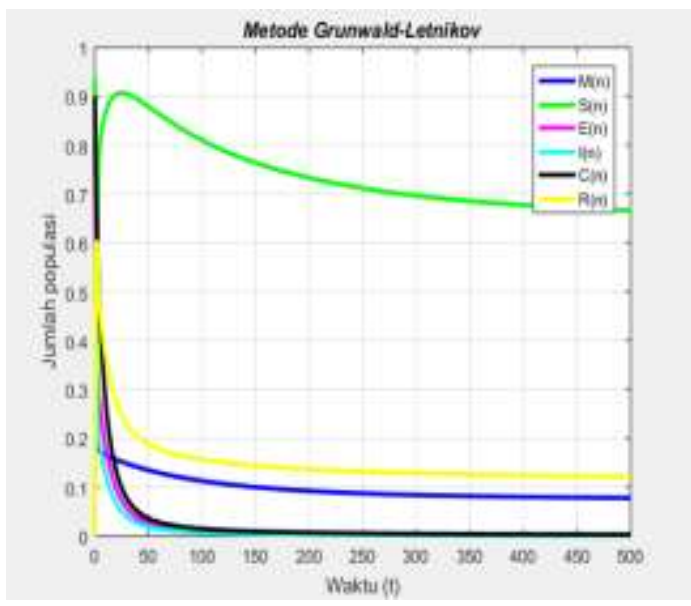

(d)

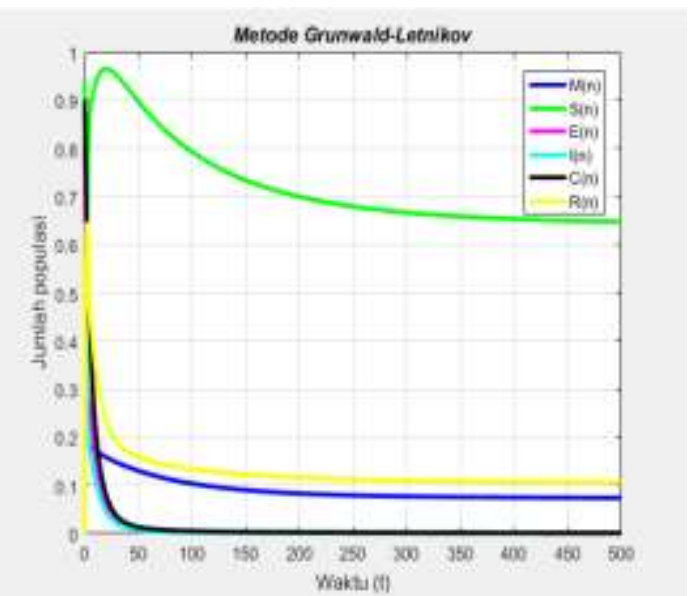

(e)

Gambar 3.1 Perubahan jumlah individu terhadap waktu dengan parameter imunisasi pada bayi yang baru lahir $c=0.1$ dan alpha fraksional $\alpha=0.5,0.75,0.8,0.9$, dan 0.95 .

Gambar 3.1 menggambarkan perilaku solusi dari sistem persamaan (3.1) dengan beberapa parameter orde fraksional orde- $\alpha$ yang berbeda. Gambar 3.1 (a) menunjukkan grafik solusi pada saat $\alpha=0.5$ pada gambar tersebut dengan nilai awal yang digunakan. Grafik pada subpopulasi $M$ dan $S$ mengalami kenaikan namun seiring bertambahnya waktu pergerakannya menjadi konstan dan konvergen menuju suatu titik. Pada subpopulasi $E$ I $C$ bahwa grafik awalnya bergerak naik lalu mengalami penurunan namun kemudian pergerakannya menjadi konstan dan konvergen menuju suatu titik. Sedangkan subpopulasi $R$ grafik menunjukkan peningkatan lalu kemudian pergerakannya menjadi konstan dan konvergen menuju suatu titik. Pada gambar 3.1 (a) ini dengan rentang waktu $t=0$ sampai $t=500$ tahun, pergerakan grafik belum mendekati titik $\Sigma_{0}=(0.088,0.772,0,0,0,0.138)$.

\section{Kesimpulan}

Hasil analisis dan simulasi yang diberikan dapat disimpulkan bahwa model matematika MSEICR pada penyebaran penyakit hepatitis B dengan pemberian vaksin dan pengobatan dengan meninjau nilai alpha fraksional $\alpha$ diperoleh dua titik kesetimbangan, yaitu titik kesetimbangan bebas penyakit $\left(\Sigma_{0}\right)$ dan endemik $\left(\Sigma_{1}\right)$. Titik kesetimbangan bebas penyakit stabil jika nilai $\mathcal{R}_{0}<1$ dan terjadi endemik jika $\mathcal{R}_{0}>1$. Jika diberikan alpha fraksional $\alpha=0.5$ maka $\mathcal{R}_{0}>1$ yang berarti terjadi endemik.jika nilai alpha fraksional ditingkatkan menjadi $\alpha=0.75$ maka $\mathcal{R}_{0}<1$ yang berarti populasi bebas dari penyakit.

Dari simulasi yang diberikan diketahui bahwa dengan memberikan nilai alpha fraksional sebesar $\alpha=0.5,0.75,0.8,0.9$ dan 0.95 , semakin besar nilai parameter orde fraksional yang digunakan, maka pergerakan grafik solusi semakin mendekati titik kesetimbangan. Pada gambar 4.1 (a) diberikan $\alpha=0.5,0.75$ dan 0.8 masih terjadi endemik sedangkan jika nilai $\alpha$ ditingkatkan menjadi 0.9 dan 0.95 maka terjadi non-endemik, akibatnya jumlah penderita hepatitis $B$ akan hilang.

\section{Daftar Pustaka}

[1] Angstmann, C. N., Henry, B. I., McGann A.V., 2016. A fractional-Order Infectivity SIR Model, Physica A, vol. 2016, pp. 86-93.

[2] Boyce, W.E. \& DiPrima, R.C., 2009. Elentary differential equation and boundary value problems 9th edition, New York: John Wiley \& Sons Inc.

[3] Das, S. \& Gupta, PK, 2011. A Mathematical model on fractional lotka volterra quations. Journal of Theoretical Biology, 277: 1-6. 


\section{Suriani.M, Syamsuddin Toaha, Kasbawati \\ Jurnal Matematika, Statistika \& Komputasi}

[4] Diethelm, K., 2010. The analysis of fractional differential Equations. Berlin : SpingerVerlag.

[5] Driessche. \& Watmough., 2002. Reproduction numbers and sub-threshold endemic equilibria for compartmental models of disease transmission. Mathematical Biosciences, Vol. 2002, No. 180, 29-48.

[6] Huo, H.F., Rui, C., Xu-Yang, W., 2016. Modeling and stability of HIV/AIDS epidemic model with treatment. Applied Mathematical Moduling, Vol 2: 6550-6559.

[7] Jinhong, 2014. Analysis of an SEIR epidemic model with saturated incidence and saturated treatment unction. The Scientific World Journal, Vol.2014:1-11.

[8] Muin, R. M., Toaha, S \& Kasbawati, 2019. Effect of vaccination and treatment on the MSEICR model of the transmission of hepatitis B virus. J. Phys.: Conf. Ser. 1341062031, doi: 10.1088/1742-6596/1341/6/062031.

[9] Rida, S.Z \& Arafa, A.A.M., 2011. New method for solving linear fractional differential equations. Int. J. Differ. Equations, Vol. 2011, p. 814132.

[10] Tri, W., Bayu, P., \& Nirmalasari, K., 2005. Pemodelan matematika dan analisis stabilitas dari penularan penyakit gonore. Buletin Ilmiah Mat. Stat. dan Terapannya (Bimaster), Vol. 4, No. 1, 47-56.

[11] Winarno, 2009. Buku Ajar: Analisis Model Dinamika Virus dalam Sel. Semarang: Universitas Negeri Semarang.

[12] World Health Organization, 2019. Hepatitis in the Western Pasific. https://www.who.int/westernpacific/health-topics/hepatitis. Diakses pada tanggal 9 Maret 2019.

[13] World Health Organization, 2017. Hepatitis. https://www.afro.who.int/healthtopics/hepatitis. Diakses pada tanggal 9 Maret 2019. 